\title{
APPENDIX 3: NAMES
}

\section{By Andreas Juckel}

\section{Treatment of the Proper Names}

For three reasons, editing and translating PChron encounters serious problems regarding the proper names. The first reason is the frequent disagreement with the Hebrew (MT), due to misinterpretation, substitution, or omission of names by the translator(s). When PChron was translated around the year $200 \mathrm{CE},{ }^{1}$ the Hebrew names were 'vocalized' by matres lectionis only. Besides the confusion of $>/$ I (yodh/waw), ד/ר (daleth/resh), and ש condition of the Hebrew Vorlage of PChron ${ }^{2}$ could have added to the distortion and omission of the names in Syriac. The second reason is the further corruption of the names during transmission in Syriac. The scribes contributed to the distortion of names by confusing,$/ ;$ (dälath/rish $),$ a

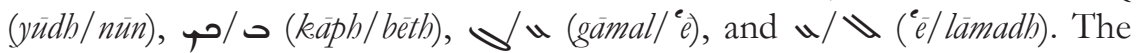
Index Nominum in the Leiden edition of PChron ${ }^{3}$ testifies to this confusion, as do the differences in names in the texts of Mosul and Leiden. ${ }^{4}$ Finally, the absence of the books of Chronicles ${ }^{5}$ from the scholarly tradition of the Syrians (i.e. from 'masoretic' manuscripts, ${ }^{6}$ commentaries, and Scholia of Bar ${ }^{e}$ Ebroyo) deprives the editor of an authentic guide to orthography and vocalization of the names. This absence is mitigated by the fact that a considerable number of names are indirectly attested by the 'Masora' of other biblical books.

\footnotetext{
1 Weitzman, The Syriac Version of the Old Testament, 258.

2 Weitzman, The Syriac Version of the Old Testament, 113. xxiii-xlv.

3 Gordon, The Old Testament in Syriac according to the Peshitta Version: IV, 2: Chronicles,

4 See above, Appendix 2b.

5 The same is true for Ezra-Nehemiah. On the transmission and reception of Chronicles in the Syriac Churches, see Phillips, 'The Reception of Peshitta Chronicles', 259_ 295.

${ }^{6}$ Ms Mingana syr. 11 (Leiden siglum: 18hm1), which includes Chronicles, is not a witness to the 'Syriac Masora' in the proper sense.
} 
The general framing of the 'Antioch Bible' does not allow for a comprehensive text-critical treatment of the proper names in PChron but must find a practical way of presenting the names in Syriac and in English. What follows gives an outline of our practical solution.

\section{Vocalization}

The earliest printed vocalized text of PChron is found in the Paris Polyglot (1645) $;^{7}$ this vocalization derives from the Maronite scholar Gabriel Sionita (Jibra'il al-Ṣahyuni, 1577-1648), ${ }^{8}$ who added vowel signs to the manuscript, which is today Ms syr. 6 of the Bibliothèque Nationale at Paris (Leiden siglum: 17a5). The vocalized text of PChron is adopted in Brian Walton's Polyglot (London 1655), ${ }^{9}$ whence derives the vocalization of the proper names in S. Lee's edition (1823). ${ }^{10}$ This line of vocalizing proper names from G. Sionita down to Lee adheres to the Western textual tradition of the Syrians and applies the five 'Greek' vowel signs; Quššāyā and Rukkākā, however, are absent.

The 'Antioch Bible' also adheres to the Western textual tradition and usually follows the Western 'Masora' in vocalizing proper names. Without guidance from the 'Syriac Masora' in PChron, it was decided to adopt the vocalization of proper names given in Walton's Polyglot. ${ }^{11}$ Many names in PChron, however, are attested by the 'Syriac Masora' of other OT books; this 'Masora'-controlled vocalization was preferred to Walton's in PChron. ${ }^{12}$ In a few cases only, the required name is neither available in Walton nor attested by the 'Syriac Masora'; here it was not difficult to vocalize by analogy with similar names. If Quššāyā and Rukkākā were not

7 Published in 10 volumes 1629-45; Chronicles is in vol. 2; see T. H. Darlow, H. F. Moule, Historical Catalogue of the Printed Editions of Holy Scripture in the Library of the British and Foreign Bible Society, vol. II,1 (London 1903), 20-22.

8 On Sionita, see G. Graf, Geschichte der christlichen arabischen Literatur vol. 3 (Rome 1949), 351-353; R. Macuch, Geschichte der spät- und neusyrischen Literatur (Berlin-New York 1976), 53-54; L. van Rompay, 'Jibra’il al-Ṣahyuni', in S. Brock, A. M. Butts, G. A. Kiraz, L. van Rompay (eds.), Gorgias Encyclopedic Dictionary of the Syriac Heritage (Piscataway 2010), 356357.

9 Published in 6 volumes 1655-57; Chronicles is in vol. 2; see Darlow and Moule, Historical Catalogue, vol. II,1, 23-26.

10 On the line of dependence of the printed texts, see G. Diettrich, Ein Apparatus criticus zur Pešitto zum Propheten Jesaias (Gießen 1905), xii-xiv; and Cl. Balzaretti, The Syriac Version of Ezra-Nebemiah (Rome 2013), 30-32.

11 This Polyglot is the best available in the reprint of 1964 (Graz-Austria, Akademische Druck- und Verlagsanstalt).

12 Some already published volumes of the 'Antioch Bible' have proved especially helpful in this respect: Joshua (2015), Samuel (2015), Exodus (2017), and Kings (2018). Genesis (forthcoming) with 'Masora'-controlled proper names was also available. 
available from the 'Syriac Masora', they were applied according to the general rules or adopted from the Mosul edition. In several cases the names included in the genealogy of Jesus (Matthew ch. 1, and Luke ch. 3) in the BFBS edition (London 1920) were helpful.

The following samples from the first chapter of 1 Chronicles show that the vocalization of proper names in Walton and in the 'Syriac Masora' are not identical. Although Walton's (i. e., G. Sionita's) vocalization ${ }^{13}$ mainly agrees with the 'Syriac Masora', it is not really based on it. ${ }^{14}$

$\mathrm{W}=$ PChron in Walton's Polyglot; 'Mas' = the 'Masoretic' proper name in Genesis (from BL Add 12,178):

\begin{tabular}{|c|c|c|}
\hline W مصّب 1 Chr 1:1 & مُبـ 'Mas' & Gen 4:25; fol 2rb \\
\hline W 1 Chr 1:2 1 نُ & 'Mas' & Gen 5:15; fol 2va \\
\hline $1 \mathrm{Chr} 1: 2$ & 'Mas' & Gen 4:18; fol 2rb \\
\hline 1 Chr 1:4 & 'Mas' a & Gen 5:32; fol 2va \\
\hline $1 \mathrm{Chr} 1: 4$ & 'Mas' & Gen 5:32; fol 2va \\
\hline 1 Chr 1:5 & 'Mas' & Gen 10:2; fol 3ra \\
\hline $1 \mathrm{Chr} 1: 5$ & 'Mas' o & Gen 10:2; fol 3ra \\
\hline ه 1 Chr 1:8 & مخرفْمر 'Mas' & Gen 10:6; fol 3ra \\
\hline W حُصحم 1:17 1 Chr 17 & 'Mas' حسخم ' & Gen 10:22; fol 3rb \\
\hline 1 Chr 1:17 & 'Mas' ;o & Gen 10:22; fol 3 \\
\hline
\end{tabular}

\section{Proper names in the English Translation}

The English translation of the 'Antioch Bible' follows the American Standard Version (ASV) of 1901 in the rendering of Syriac names of biblical persons, towns and countries. This basic principle fails when the Syriac text and the ASV are not matching at all or differ too much. As the ASV is based on the Hebrew, serious textual differences with the Syriac are possible, esp. in PChron. The inadequacy of the ASV to render the Syriac was felt for the first time in Joshua, when the translators came across many unique names

13 What is the source of G. Sionita's vocalizing? As a Maronite scholar, he could have been influenced by the Western and Eastern textual traditions of the Syrians as well as by Arabic and Latin.

14 The differences between Walton and the 'Syriac Masora' call for a thorough check of proper names by documentary ('Masoretic') evidence. A future concordance of proper names in the OT-Peshitta will have to quote the 'Masoretic' reading(s), including Quššāāā/ Rukkākā. 
of persons, towns and cities incompatible with the ASV. A system of transcription solved the problem. ${ }^{15}$

In PChron, the problem of inadequacy becomes worse because of the greatly increased number of rare or unique names. An additional problem is the formation of the Syriac names through obvious corruption or distortion during translation and transmission. Transcribing the corruption without comment would confuse the reader who compares the English translation with his or her familiar text; correcting the corruption (if possible) would introduce the Hebrew as the normative text, which the Syriac had 'failed' to render appropriately. How, then, should we acknowledge the primacy of the Syriac in the English translation, without acknowledging the numerous corruptions?

In PChron the primacy of the Syriac is acknowledged by transcribing and introducing the required names whenever the Syriac and the ASV do not match at all or differ too much. Besides incompatible portions of text, there are series of proper names incompatible with the ASV. ${ }^{16}$ In addition, the use of the ASV is expanded and put into a Syriac perspective: Whenever rare and unique Syriac names can be identified in the ASV (although not matching completely), the ASV is adopted unchanged. Basically, the identification relies on the identity of consonants, while the vowels are neglected. ${ }^{17}$ The identity of consonants, however, is not strictly observed, especially when changes of consonants are due to confusion by transmission in Syriac. ${ }^{18}$ The intention of the expanded use of the ASV is not to correct the Syriac but to understand the (mis)formation of rare and unique Syriac names by comparison with the ASV (i.e. indirectly with the Hebrew). The indispensable condition for this expanded use is the recognizable correspondence between Syriac proper names and the ASV. If the correspondence is not recognizable, the names are transcribed.

\footnotetext{
15 See the Joshua volume (2015), xxv-xxvii. It is not a scientific transcription proper but is consistent and adapted to the ASV.

16 They are not marked in the English translation. The transcription follows the rules given in the Joshua volume.

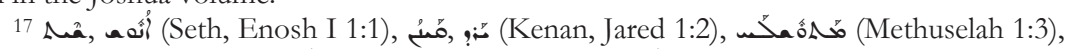

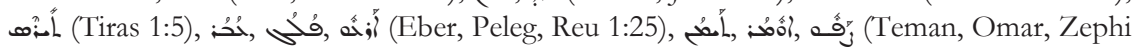

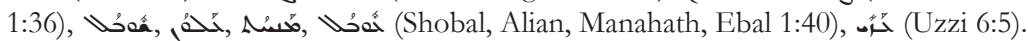

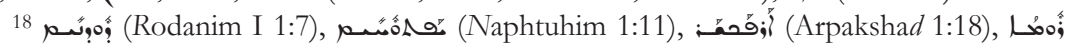

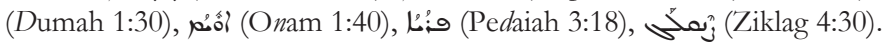

